\title{
Adminitrasi Hubungan sekolah dan masyarakat
}

Abstrak - Educational Administration is related activity or the entire business coordination process that is combined with people to achieve educational and planning goals held in certain environments using resources, both human and non-human, school-sponsored and community- sponsored. Husemas are process of communication between schools and the community to improve people's understanding of educational needs and activities and endcourage community interest and cooperation in school improvement and development. Public relations as a liaison from the school and the community must always be maintained properly because the school will always be in touch with the community, cannot escape from it as a school partner in achieving the success of the school itself. School achievement is increasingly high in the eyes of the community if the school is able to gather students who are intelligent, personable and able to apply the knowledge gained in advancing society A.Pengertian Administrasi Hubungan Sekolah dan Masyarakat 1.Pengertian Administrasi Dalam kamus Koenen's Endepols: Administrasi (Belanda: administratie) berasal dari bahasa Latin "administration" dengan kata kerja“administrare" yang berarti mengemudikan, mengendalikan, dan mengawasi pelaksanaannya.Dalam arti sempit administrasi berarti pekerjaa tulis menulis (Inggris: clerical work). Sedangkan dalam arti luas, administrasi merupakan kegiatan yang komperehensip (menyeluruh), yakni yang bersangkutan dengan pengolahan keseluruhan dari awal hingga mencapai hasil akhir. Administrasi sekolah merupakan perpaduan dari dua buah kata yakni "administrasi" dan "sekolah" yang masingmasing memiliki makna tersendiri.ditinjau dari segi katanya administrasi mempunyai arti sempit dan arti luas. Dalam arti sempit administrasi diartikan sebagai kegiatan pencatatan data, surat-surat, informasi secara tertulis serta penyimpanan dokumen sehingga dapat dipergunakan kembali bila diperlukan (paul mahieu,1948) dalam hal ini kegiatan administrasi meliputi pekerjaan tata usaha, yaitu melayani dan membantu pimpinan organisasi dalam mempersiapkan surat menyurat, mencatat dan menyimpan arsip-arsip, data dan bahan informasi yang diperlukan dalam pengambilan keputusan. Dalam arti luas, administrasi menyangkut kegiatan manajemen atau pengelolaan terhadap keseluruhan komponen organisasi untuk mewujudkan tujuan atau program organisasi. Dengan demikian dapat dikatakan bahwa pekerjaan administrasi merupakan pekerjaan operatif dan manajemen (Louis A. Allen). Administrasi sekolah merupakan bagian dari administrasi pendidikan. administrasi pendidikan meliputi kegiaatan-kegiatan yang berhubungan dengan pengelolaan pendidikan di suatu negara atau bahkan pendidikan pada umumnya. Sedangkan administrasi sekolah kegiatan-kegiatannya terbatas pada pelaksanaan pengelolaan pendidikan di sekolah sehingga kita mengenal adanya administrasi sekolah dasar, administrasi sekolah lanjutan, administrasi perguruan tinggi, dan sebagainya.

2. Pengertian Administrasi Hubungan Sekolah dengan Masyarakat Pengertian administrasi hubungan sekolah dengan masyarakat merupakan seluruh proses kegiatan yang direncanakan dan diusahakan secara sengaja atau sungguh-sungguh serta pembinaan secara kontinu untuk mendapatkan simpati dari 
masyarakat pada umumnya serta dari publik pada khususnya, sehingga kegiatan operasional sekolah atau pendidikan semakin efektif dan efisien demi membantu tercapainya tujuan pendidikan yang telah ditetapkan. Humas sebagai penghubung dari pihak sekolah dengan masyarakat harus selalu dipelihara dengan baik karena sekolah akan selalu berhubungan dengan masyarakat, tidak bisa lepas darinya sebagai partner sekolah dalam mencapai kesuksesan sekolah itu sendiri. Prestise sekolah semakin tinggi di mata masyarakat jika sekolah mampu melahirkan peserta didik yang cerdas, berkepribadian dan mampu mengaplikasikan ilmu yang diperolehnya dalam memajukan masyarakat. Sekolah harus selalu siap mengantarkan peserta didik terjun langsung ke masyarakat diantaranya dengan membekali peserta didik dengan pengetahuan, nilai-nilai dan ketrampilan- ketrampilan khusus baik melalui kegiatan intra maupun ekstra. Jadi bila kita tarik garis merah secara general, maka pengertian hubungan sekolah dengan masyarakat adalah rangkaian kegiatan organisasi atau instansi untuk menciptakan hubungan yang harmonis dengan masyarakat atau pihak-pihak tertentu di luar organisasi tersebut, agar mendapatkan dukungan terhadap efisiensi dan efektivitas pelaksanaan kerja seara sadar dan sukarela

B. Prinsip-Prinsip dan Teknik Hubungan Sekolah-Masyarakat Dalam melaksanakan kegiatan hubungan sekolah-masyarakat perlu dianut beberapa prinsip. Prinsip ini memberikan pedoman dan arah kepada guru dan kepala sekolah, sehingga kegiatan hubungan sekolah-masyarakat itu dapat mencapai sasaran yang telah ditetapkan. Prinsip-prinsip itu adalah: a) Prinsip otoritas, yaitu bahwa husemas harus dilakukan oleh orang yang mempunyai otoritas, karena pengetahuan dan tanggung jawabnya dalam penyelenggaraan sekolah. b) Prinsip kesederhanaan, yaitu bahwa program-program hubungan sekolahmasyarakat harus sederhana dan jelas. c) Prinsip sensitivitas, yaitu dalam menangani masalah-masalah yang berhubungan dengan masyarakat, sekolah harus sensitive terhadap kebutuhan serta harapan masyarakat. Apa yang dianggap biasa oleh sekolah dapat merupakan hal yang sangat menyinggung perasaan masyarakat. d) Prinsip kejujuran, yaitu bahwa apa yang disampaikan kepada masyarakat haruslah sesuatu apa adanya dan disampaikan secara jujur. Sekali sekolah memberikan informasi yang tidak benar, kepercayaan masyarakat terhadap sekolah akan menurun, dan akibatnya sekolah tidak lagi mudah untuk membangun kepercayaan itu kembali. e) Prinsip ketetapan, yaitu bahwa apa yang disampaikan sekolah kepada masyarakat harus tepat, baik baik dilihat dari segi isi, waktu, media yang digunakan serta tujuan yang akan dicapai. Pemilihan waktu yang kurang tepat dapat mengakibatkan kegagalan dari program tersebut. Selain itu ada juga beberapa prinsip yang dipakai dalam administrasi hubungan sekolah dan masyarakat, Yaitu : 1) Integrity Prinsip ini mengandung makna bahwa semua kegiatan hubungan sekolah dengan masyarakat harus terpadu, dalam arti apa yang dijelaskan, disampaikan dan disuguhkan kepada masyarakat harus informasi yang terpadu antara informasi kegiatan akademik maupun informasi kegiatan yang bersifat non akademik. Biasanya sering terjadi sekolah tidak menginformasikan atau menutupi sesuatu yang sebenarnya menjadi masalah sekolah dan perlu bantuan atau dukungan orang tua murid. Oleh sebab itu sekolah harus sedini mungkin mengantisipasi kemungkinan adanya salah persepsi, salah 
interpretasi tentang informasi yang disajikan dengan melengkapi informasi yang akurat dan data yang lengkap, sehingga dapat diterima secara rasional oleh masyarakat. Hal ini sangat penting untuk meningkatkan penilaian dan kepercayaan masyarakat atau orang tua murid terhadap sekolah, atau dengan kata lain transparansi sekolah sangat diperlukan, lebih-lebih dalam era reformasi dan abad informasi ini, masyarakat akan semakin kritis dan berani memberikan penilaian secara langsung tentang sekolah. 2) Continuity Prinsip ini berarti bahwa pelaksanaan hubungan sekolah dengan masyarakat, harus dilakukan secara terus menerus. Jadi pelaksanaan hubungan sekolah dengan masyarakat tidak hanya dilakukan secara insedental atau sewaktu-waktu, misalnya satu kali dalam satu tahun atau sekali dalam satu semester, hanya dilakukan oleh sekolah pada saat akan meminta bantuan keuangan kepada orang tua atau masyarakat. Hal inilah yang menyebabkan masyarakat selalu beranggapan apabila ada panggilan sekolah untuk datang kesekolah selalu dikaitkan dengan uang. Akibatnya mereka cenderung untuk tidak menghadiri atau sekedar mewakilkan kepada orang lain untuk menghadiri undangan sekolah. Apabila ini terkondisi, maka sekolah akan sulit mendapat dukungan yang kuat dari semua orang tua murid dan masyarakat.

3)Simplicity Prinsip ini menghendaki agar dalam proses hubungan sekolah dengan masyarakat yang dilakukan baik komunikasi personal maupun komunikasi kelompok pihak pemberi informasi (sekolah) dapat menyederhanakan berbagai informasi yang disajikan kepada masyarakat. Informasi yang disajikan kepada masyarakat melalui pertemuan langsung maupun melalui media hendaknya disajikan dalam bentuk sederhana sesuai dengan kondisi dan karakteristik pendengar (masyarakat setempat). Prinsip kesederhanaan ini juga mengandung makna bahwa: informasi yang disajikan dinyatakan dengan kata-kata yang penuh persahabatan dan mudah dimengerti. Banyak masyarakat yang tidak memahami istilah-istilah yang sangat ilmiah, oleh sebab itu penggunaan istilah sedapat mungkin disesuaikan dengan tingkat pemahaman masyarakat.

3) Coverage Kegiatan pemberian informasi hendaknya menyeluruh dan mencakup semua aspek, faktor atau substansi yang perlu disampaikan dan diketahui oleh masyarakat, misalnya program ekstra kurikuler, kegiatan kurikuler, remedial teaching dan lain-lain kegiatan. Prinsip ini juga mengandung makna bahwa segala informasi hendaknya: a.Lengkap masyarakat. b. Akurat c.Up to date

4) Constructiveness Program hubungan sekolah dengan masyarakat hendaknya konstruktif dalam arti sekolah memberikan informasi yang konstruktif kepada masyarakat. Dengan demikian masyarakat akan memberikan respon hal-hal positif tentang sekolah serta mengerti dan memahami secara detail berbagai masalah yang dihadapi sekolah. Apabila hal tersebut dapat mereka mengerti, akan merupakan salah satu faktor yang dapat mendorongmereka untuk memberikan bantuan kepada sekolah sesuai dengan permasalahan sekolah yang perlu mendapat perhatian dan pemecahan bersama 5) Adaptability Program hubungan sekolah dengan masyarakat hendaknya disesuaikan dengan keadaan di dalam lingkungan masyarakat tersebut. Penyesuaian dalam hal ini termasuk penyesuaian terhadap aktivitas, kebiasaan, budaya ( culture) dan bahan informasi yang ada dan berlaku di dalam kehidupan masyarakat. Bahkan 
pelaksanaan kegiatan hubungan dengan masyarakat pun harus disesuaikan dengan kondisi masyaraka

Daftar Pustaka : Daftar pustaka harus menggunakan software Mendeley dengan benar. Lihat tutorialnya di video youtube. Contoh : Afriansyah, H. (2019).

Administrasi Peserta Didik. Padang. https://doi.org/10.17605/OSF.IO/NRXH8 A 